\title{
Corporate Sustainability in Fashion and Luxury Companies
}

\author{
Elisa Arrigo*
}

\begin{abstract}
The paper deepens the notion of corporate sustainability in the fashion and luxury sector in order to highlight the key sustainability issues that companies operating in these markets face. In particular, to provide a more faithful depiction of corporate sustainability in the fashion industry, two apparently opposed fashion market segments (mass-market and luxury) are analyzed. The findings show that sustainability is a critical driver of growth for both mass-market and luxury companies. In fact, they are all committed in seeking new technologies and procedures aimed at pursuing a sustainable development where the focus on profit, the planet and people are in balance.
\end{abstract}

Keywords: Corporate Sustainability; Sustainable Development; Fashion Industry; Luxury Industry; Global Markets

\section{Fashion and Luxury in the Global Market}

Fashion and luxury are among the most polluting industries in the business world due to their heavy use of chemicals and non-renewable resources for production processes such as dyeing and tanning (Gardetti \& Torres, 2013; Pedersen \& Andersen, 2015). Furthermore, many European and US fashion companies have expanded their activities beyond their country of origin by pursuing a market-space management approach (Brondoni, 2008). This has led to outsourcing and delocalization policies and the creation of global supply chains (Keegan \& Green, 2013) composed of several subcontractors and suppliers mainly located in lowwage countries. The pressure to fulfill the tripe-bottom lines (economic, social and environmental performance) has thus increased as more and more consumers demand higher transparency of fashion businesses' operations.

Meantime, fashion and luxury companies have reinforced their corporate sustainability values and spread awareness among external stakeholders to defend their brands from the accusation of damaging the ecological and social environment. In fact, corporate sustainability has emerged as a new managerial model based on stakeholder relationships and the capacity to integrate strategically economic, social and environmental issues into business operations (Perrini \& Vurro, 2010).

\footnotetext{
* Assistant Professor of Management. University of Milan-Bicocca (elisa.arrigo@ unimib.it)
} 
The aim of this paper is to deepen the notion of corporate sustainability in fashion and luxury companies in order to highlight and compare the key sustainability policies realized by fashion companies operating in mass-market and luxury fields.

The paper is structured as follows: after the introduction, Section 2 analyses the theoretical background of sustainable development and corporate sustainability, Section 3 examines the features of corporate sustainability in fashion and luxury companies. Section 4 contains the methodology's description and an examination of the issues and priorities recognized by the selected case studies with regard to the economic, social and environmental sustainability; and, finally, Section 5 draws some conclusions with limitations and future research directions.

\section{Sustainable Development and Corporate Sustainability}

The concept of Sustainable Development has received much attention in the last decades. In 1987, the World Commission on Environment and Development (WCED) published the Brundtland Report that defined sustainable development as a "development that meets the needs of the present without compromising the ability of future generations to meet their needs" (WCED, 1987, p. 43). According to this report, the three pillars of sustainability were "people, profit and planet"; however, in 2002, the World Summit on Sustainable Development in Johannesburg changed them in "people, planet and prosperity".

In 1994, John Elkington coined the expression "Triple Bottom Line" (Elkington, 1994; 1997) to specify that companies can achieve a sustainable development only if three elements, namely the social, economic and environmental aspects, balance it. Thus, the topic of sustainability started to represent a vital aspect for businesses since socio-environmental problems became more and more severe and, frequently, companies were a target for public criticism and accusations.

The concept of corporate sustainability refers to sustainability at an organizational level by being a multi-faceted paradigm that involves environmental, social and economics results (Carcano, 2013). It focuses on the company ability to satisfy the needs of its stakeholders (customers, shareholders, employees, community, etc.) without compromising the ability to satisfy those of future stakeholders (Dillick \& Hockerts, 2002). Obviously, to be successful for the company and its stakeholders, corporate sustainability policies should be integrated into a long run development strategy, pertaining to many corporate processes such as: transformation, product design, human resources management, etc. (Epstein, 2008). Moreover, as stated by Bansal (2005), sustainable companies need to pursue an environmental integrity, an economic prosperity, and a social equality in both their products and policies.

In order to better examine the concept of corporate sustainability, it is relevant to point out some aspects. Firstly, it bases itself on the stakeholder theory (Freeman, 2010) that expands the company boundaries to a wide set of stakeholders, far beyond the customers. Furthermore, nowadays, the pressure toward sustainability has pushed companies to become responsible for not only their direct activities but also for those of their supply chain partners. Consequently, the topic of "sustainable supply chain management" has become very complex and the definition and management of sustainable policies inside a companies' network branched on a global level represents a big competitive challenge. Finally, another key aspect of 
corporate sustainability concept pertains the shifting of the business focus from the only financial dimension to the three bottom line approach in which the economic, environmental and social dimensions should be equally relevant.

In the managerial academic literature, three main conceptual approaches to corporate sustainability have been distinguished: the first contemplates environmental and social sustainability policies as a tool for reaching a competitive advantage; the second involves the measurement of sustainability performance; and the last one focuses on proposing multidimensional measures of corporate sustainability (Carcano, 2013).

Modifying corporate processes and products to make them greener can be very costly and may put a company pursuing a similar policy in a loser competitive position with respect to its competitors. However, recent research has shown that sustainability can be a source of organizational and technological innovations for companies (Nidomolu et al., 2009); in fact, becoming more environment-friendly can lower the total production cost since companies reduce the use of nonrenewable resources and, furthermore, the resulting products usually offer a better performance. According to Nidomolu et al. (2009), companies that started a process to become sustainable, went through the following subsequent stages:

- Compliance with norms as opportunity: if companies stay focused on emerging norms, may gain time to try new materials, technologies and processes before competitors and enjoy a fist mover position. Moreover, the conformance to unique global sustainable standards helps firms to save money; otherwise being compliant to many different local environmental regulations could be very costly and time wasting.

- Making supply chains more sustainable: companies try to become more efficient by reducing the consumption of petroleum, coal, gas, and water along the entire supply chain. For example, they provide suppliers with incentives to develop sustainable practices in their activities and tools to measure their environmental impact. Some corporations make use of employees working from home, in this way they may reduce or even eliminate the travel time, travel costs and energy consumption.

- Developing sustainable products: companies provide customers with ecofriendly offerings and by looking for sustainable products and services develop innovative products such as the company $P \& G$ that after stating the high annual US energy consumption, decided to create cold-water detergents with a lower energy cost and a compact packaging.

- Developing sustainable business models: able to enhance customer value propositions by looking for new ways for meeting customer needs. It is relevant to underline how if the path toward a sustainable development frequently starts from the top management, the change will be faster and wider since the entire supply chain could benefit of it.

The increasing pressure to meet sustainability requirements has pushed several companies to develop sustainable programs to monitor and assess their processes. In fact, companies pursuing a sustainable path disclose data and information about their economic, social, and environmental performance and sustainability programs in publicly available reports. These are often based on global reporting systems such as the Global Compact or Global Reporting Initiative (GRI) guidelines that 
help companies to set goals, evaluate performance and drive a change to become more sustainable.

\section{Corporate Sustainability in Fashion Companies}

The fashion industry is one of the prominent industries worldwide and many academic papers critically examined its impact on the social and ecological environment (Jia et al., 2015). In addition, fashion constitutes a very complex industry where both artisan tailors, multinational fashion retailers, and luxury corporations operate, ranging from haute couture and prêt-à-porter, to diffusion, bridge, and mass-market. In the academic literature, two different views have been proposed regarding the influence of environmental and social sustainability on economic sustainability in fashion companies (Khurana \& Ricchetti, 2015).

The first one is focused on analysing the negative consequences of business actions on the environment by determining the unpaid costs of this use; in this case, the adoption of sustainable practices would mean to invest money into by increasing the total costs. On the contrary, the second view considers sustainability as an attribute of processes and products that is beneficial for stakeholders by leading to innovation and value generation (Kapferer, 2010).

The latter approach to sustainability seems the most appropriate to fashion and luxury management since it addresses more closely to the intangible component of fashion and luxury brands and its effect on the brand reputation. In fact, this constitutes one interesting incentive to develop sustainable initiatives. Obviously, similar initiatives should be managed and evaluated in an integrated approach that considers the trade-offs between environmental impacts, economic results and social consequences (de Brito et al., 2008).

However, as highlighted by Kozlowski, Searcy, and Bardecki (2015), some difficulties arise in embedding sustainability in the fashion industry depending mainly on three reasons. Firstly, it does not exist a stated understanding of what sustainability means from an operational perspective. Secondly, the fashion sector is split into many retail market segments, and the issues associated with sustainability in each segment are different (a unique solution does not exist). Finally, the creation of global fashion supply chains has made complex both their management and the introduction and management of sustainability practices through the numerous supply chain members (suppliers, manufacturers, distributors, retailers, etc.). Therefore, to provide a more faithful depiction of sustainability policies in the fashion industry, in the following paragraphs, corporate sustainability will be analyzed in the two apparently opposed fashion segments: mass-market and luxury fashion market.

\subsection{Corporate Sustainability in Mass-Market Fashion}

The mass-market fashion primarily regards the clothing field, which is probably the most affected by sustainability concerns. In fact, the globalization of markets and the advent of new technologies has led to the creation of global fashion supply chains where rapidity, flexibility, quick response approach and low cost represent the key drivers of success. Nevertheless, this new business model caused relevant 
effects on the fashion market, which are strictly related to social and environmental sustainability issues. In fact, together with the growth of the fashion demand caused by the reduction of clothing price and the wide availability of fashion offerings, an increasing massive use started of natural resources, such as water, energy, cotton, textiles and also chemicals, synthetic materials, pesticides, etc. For example, just think that cotton production accounts for $10 \%$ of all synthetic pesticides and for 20 $25 \%$ of insecticides applied worldwide each year and, as it is well-known, many pesticides are persistent in the environment (Achabou \& Dekhili, 2013). Furthermore, global logistics' processes from suppliers' factories to the country of origin of fashion companies generate heavy negative effects on the environment. In particular, the choice of transportation modes (truck, rail, water, pipeline, and air), beside to affect the final price of products and their time to market, has dissimilar environmental impacts in terms of $\mathrm{CO} 2$ emissions.

In addition, outsourcing and delocalization strategies realized by fashion companies faced the adoption of unfair labour practices in foreign manufacturing markets such as child labour, low wages, overwhelming working hours, and other health issues. Similarly, a limited transparency existed on where and how clothes were made (Perdersen \& Andersen, 2015) and relocation strategies set also difficulties in the control of working conditions in offshore sites by creating social sustainability challenges. Finally, the fast fashion business model emphasized a new approach to the consumption of fashion garments that were bought to be worn for a limited period of one or two seasons and then end up as waste by creating a big damage for the environment (Kozlowski et al., 2015). For this reason, expressions such as 'MacFashion', similar to McDonalds, or also 'Disposable Fashion' have been coined to refer to fast fashion clothing that can be acquired at a low-cost and then discarded (Choi et al., 2010). More and more consumers are now criticizing the logic of producing large amounts of low-cost products that stimulate an excessive consumption, and ethical fashion movements, such as 'Slow Fashion', have recently appeared along with sustainable considerations (Kim et al., 2013).

However, despite all the criticisms, it seems worth to emphasize how companies operating in the fashion apparel industry have been among the first ones to pay attention to sustainability issues with the development of codes of conduct for suppliers at early 1990s. In subsequent years, clothing brands have taken various actions to show their commitment to corporate sustainability such as the creation of sustainability committees or work teams, or the development of sustainability programs, and the publication of sustainability reports (Kozlowski et al., 2015). Industrial initiatives have been also developed such as the Sustainable Apparel Coalition (SAC), or the Alliance for Bangladesh Worker Safety built after the tragic event occurred in 2013 in the apparel industry.

From the examination of the sustainability programs implemented by fast fashion companies, Turker and Altuntas (2014) revealed a clear focus on the supplier compliance with their code of conduct, and on further monitoring and auditing activities to prevent production problems in developing countries. However, beside to stimulate sustainable practices at suppliers, fast fashion brands attest that their products meet the most stringent health and safety standards by using materials obtained from sustainable sources. For example, at Inditex, raw material choices result from the biodiversity, water and energy management strategies. Several company brands have product lines and collections made exclusively from certified 
organic cotton (Inditex website), which is farmed without the use of chemicals such as fertilizers and pesticides and its production is increased hugely in the last years (Achabou \& Dekhili, 2013). A similar sustainable commitment characterizes H\&M that uses both natural and recycled materials for its collections; it is possible to cite among them: organic leather; recycled wool; organic linen, hemp, and silk; natural rubber; recycled polyester and polyamide, and even recycled glass used for embellishments dresses (H\&M website). An additional key aspect of sustainability policies in mass-market fashion field concerns waste management; in fact, as argued by Sandy Black, author of "The Sustainable Fashion Handbook" (2013), as fashion is becoming faster and cheaper, it is more wasteful. To counter this trend, the most advanced fast fashion companies evaluate the total environmental impact of their goods from cradle to grave and some of them pursue also a loop economy "from cradle to a new cradle" based on re-cycling materials or products (Lambin, 2009). For example, on its company website, H\&M declares to go "towards $100 \%$ circularity" and specifies that "Moving towards a 100\% circular business model means nothing less than completely turning around how our industry has been operating for decades...But becoming $100 \%$ circular goes a lot further than recycling. It is about developing solutions and business models to extend the lifespan of products from different perspectives and by having a circular approach in how products are manufactured and used. .... just imagine all the repairing and mending that can be done; replacing zips, taking up hems, patching jeans - there are many ways to prolong a garment's life, before it eventually can be recycled in a closed loop" (H\&M website). Similarly, Inditex in its annual report declares to follow a circular economy model "with the Closing the Loop project, which combines environmental and social sustainability to pursue the goal of ensuring no used textile item ends up in landfill" (Inditex Annual Report, 2015).

Starting from the design stage, it is essential to examine the product longevity and lifecycle issues, such as the washing of clothing, to evaluate environmental impact. Experimentation in the search for a more sustainable approach to fashion may lay to find new ways and tools to reduce the fashion's impact on the planet by using, for example, three-dimensional scanning to measure customer body for 3D knitting (Petrick \& Simpson, 2013). In so doing, manufacturing steps are reduced and likewise the deriving waste, because clothes are made in one piece to fit the individual's shape and, consequently, the benefits of tailored fashion and economical mass customization are combined (Black, 2013).

\subsection{Corporate Sustainability in Luxury Fashion}

The concept of "sustainable luxury" is considered as an oxymoron by someone since sustainability is based on a respect for the environment and society, by evoking the values of altruism and ethics, while luxury symbolizes wasteful, thoughtless, personal pleasure, superficiality and ostentation (Cervellon \& Shammas, 2013; Acabou \& Dekhili, 2013). Consequently, the luxury sector has been frequently under scrutiny and this was not well accepted by luxury brands that supposed to represent the excellence. In reality, as suggested by Kapferer (2010), a deeper examination of luxury and sustainable development reveals how luxury and sustainability tend to converge on some specific aspects that are going to be described. 
Traditionally, luxury was a prerogative of rich and powerful people but, over the time, this has changed due to the luxury democratization process (or massification) that occurred when artisanal luxury companies faced the competition of large multinational corporations, which had a strong focus on economic aspects ( $\mathrm{Li}$ et al., 2015). However, the recent economic recession has determined a retour to the ancient value of luxury based on a great rarity, which derives from the scarcity of used materials, applied craftsmanship, and artistry (Gardetti \& Muthu, 2015).

Luxury companies are thus committed to preserve natural resources such as leather, pears, and silk that are key components of their offers. Moreover, luxury products are often rare and scarce depending on their small manufacturing in limited quantity, and consequently they limit the environment's consumption (Kapferer, 2010). The described approach is completely opposite to that of mass production where the over fabrication of consumer goods far exceeds their recycling capacities. Furthermore, luxury management is not aimed at obtaining cost reduction, instead at creating customer value through uniqueness and beauty of luxury items that often are made in the home country of luxury companies without pursuing a de-localization logic.

Stated the relevance of crafted, handmade and rare savoir faire, luxury companies have the problem to preserve luxury artisanship skills over time and, for this reason, frequently they invest in sustainable programs focused on employees' training or building artisan schools where young people can learn the ancient jobs. For example, Brunello Cucinelli founded the "School of Craftsmanship" in Solomeo where attendants learn the following disciplines: mending and linking, cutting and assembly, tailoring, and masonry. "The significance of the school is certainly that of a long-cherished dream and at the same time the significant application of a new revolutionary concept of humanistic capitalism that Brunello created and put into practice. From this came the ideal motive for the school: to restore craftsmanship's nobility and pay appropriate wages for this specialised type of work. This is, in fact, the long-term goal of the Solomeo School: to reverse this tendency and start a regenerative process - a sort of neo-renaissance of the noble values of craftsmanship - while giving young people trust in the future once more" (Brunello Cucinelli website).

Beyond rarity and beauty, luxury products hold the feature of durability that is at the basis of each sustainable development. Customers perceive buying a luxury product as a sort of investment (Hennings et al., 2013); in fact, for example, luxury bags and jewels are handed down from generation to generation exactly due to the durable quality of their materials. This trend contrasts the 'throwaway' logic of fast fashion where clothes are assimilated to convenience goods conflicting with a sustainable development and a long-term perspective.

\section{An Examination of Environmental Social and Economic Sustainability in Fashion and Luxury Companies}

In order to highlight the most important sustainability priorities recognized by fashion and luxury companies, the literature review provided in the background section is associated here to an examination of selected case studies (Yin, 2013) 
based on the content analysis (Krippendorff, 2012) of their annual reports and sustainability reports (Tate et al., 2010).

To provide a wider description of sustainable policies pursued in fashion industry the case studies pertain to the different markets of fast fashion and luxury. They are Inditex and $H \& M$ in the fast fashion market and Kering and Louis Vuitton Moët Hennessy (LVMH) in the luxury one.

In the Table 1, a brief description of the fashion groups is provided.

The selection of the fashion companies for the case studies has been based on two criteria:

- $\quad$ they have a leading position in their market, and

- $\quad$ they structure their reports in accordance with the guidelines of the Global Reporting Initiative (GRI) that evaluates economic, social and environmental performance.

Table 1: Companies' Description

\begin{tabular}{|c|c|c|c|c|}
\hline Country & Inditex & H\&M & Kering & LVMH \\
\hline $\begin{array}{c}\text { Spanish } \\
\text { Company } \\
\text { employees }\end{array}$ & $\begin{array}{c}\text { Swedish } \\
\text { Company }\end{array}$ & $\begin{array}{c}\text { French } \\
\text { Company }\end{array}$ & $\begin{array}{c}\text { French } \\
\text { Company }\end{array}$ \\
\hline $\begin{array}{c}\text { Turnover } \\
(\mathbf{2 0 1 5})\end{array}$ & $\begin{array}{c}20.9 \text { billion } \\
\text { euro }\end{array}$ & $\begin{array}{c}21.4 \text { billion } \\
\text { euro }(210 \\
\text { billion SEK) }\end{array}$ & $\begin{array}{c}11.6 \text { billion } \\
\text { euro }\end{array}$ & $\begin{array}{c}35.7 \text { billion } \\
\text { euro }\end{array}$ \\
\hline $\begin{array}{c}\text { Commercial } \\
\text { Presence }\end{array}$ & 88 countries & 61 countries & 120 countries & 70 countries \\
\hline
\end{tabular}

Source: Companies’ Annual Reports (2015)

The examination of annual and sustainability reports has been carried out by splitting the sustainability priorities recognized by each company in three sections following the Triple Bottom Line Approach (Elkington, 1994, 1997), namely based on the three Ps:

- profit: strategies aimed at improving the financial performance,

- $\quad$ planet: strategies designed to preserve the ecological environment,

- people: strategies directed at adopting socially responsible policies in operations and retailing.

In Tables 2 and 3, the results of the analysis are summarized.

In the fast fashion market, from an economic sustainability perspective, Inditex and $\mathrm{H} \& \mathrm{M}$ pursue a global development policy primarily based on:

- a low-diversified multi-brand portfolio (only the main store brand in each company portfolio pertains to the furniture market, namely H\&M Home and Zara Home);

- $\quad$ continual new store openings and online commerce reinforcement;

- digitalization and new technologies' adoption. 
Table 2: Focus on profit, planet and people at Inditex and $H \& M$

\begin{tabular}{|c|c|c|}
\hline & H\&M & Inditex \\
\hline $\begin{array}{l}\mathbf{p} \\
\mathbf{r} \\
\mathbf{o} \\
\mathbf{f} \\
\mathbf{i} \\
\mathbf{t}\end{array}$ & $\begin{array}{l}\text { With a total of 3,924 stores, H\&M operates six fashion } \\
\text { brands (H\&M, COS, \&OtherStories, CheaoMonday, Monki, } \\
\text { Weekday). Sustainability is an integral part of its business. } \\
\text { Conscious is the H\&M plan for sustainability based on } \\
\text { seven commitments, each with several Conscious Actions: } \\
\text { provide fashion for conscious customers; choose and } \\
\text { reward responsible partners; be ethical; be climate smart; } \\
\text { reduce, reuse, recycle; use natural resources responsibly; } \\
\text { strengthen communities. } \\
\text { As a company with strong values and a long-term } \\
\text { approach, it wants to use its size and influence to bring } \\
\text { about better conditions for people and to minimise } \\
\text { environmental impact throughout the value chain. Progress } \\
\text { is achieved through collaborations, innovation and greater } \\
\text { transparency. The strong expansion of H\&M continues } \\
\text { both through store opening and online. Long-term } \\
\text { investments are being made in IT and online in order to } \\
\text { accommodate the possibilities brought about by an } \\
\text { increased digitalisation. The growth target is to increase the } \\
\text { number of stores by } 10-15 \text { percent per year with continued } \\
\text { high profitability. }\end{array}$ & $\begin{array}{l}\text { The Inditex Group closed fiscal year } 2015 \text { with a total of } \\
7,013 \text { stores and eight brands -Zara, Pull\&Bear, Massimo } \\
\text { Dutti, Bershka, Stradivarius, Oysho, Zara Home and } \\
\text { Uterqüe. It has increased the commercial presence with new } \\
\text { openings and significant extended reopenings worldwide, } \\
\text { completing this expansion with the integrated development } \\
\text { of online sale platforms. Inditex foresees significant } \\
\text { opportunities of growth and continues with the global } \\
\text { expansion of its integrated store and on-line sales model. In } \\
\text { the coming years, } 6 \%-8 \% \text { growth is envisaged in new retail } \\
\text { space in prime locations and organic and on-line sales are } \\
\text { expected to make an increasing contribution. The Group has } \\
\text { been run with the help of the technology available in all } \\
\text { areas of activity in order to improve manufacturing and } \\
\text { distribution proces ses, and by developing in-house or third } \\
\text { party tools to facilitate the management of the business. } \\
\text { Some examples are point-of-sale terminals, inventory } \\
\text { management systems, distribution center delivery systems, } \\
\text { systems for communications with stores, and in-store } \\
\text { garment labeling systems. }\end{array}$ \\
\hline $\begin{array}{l}\mathbf{p} \\
\mathbf{l} \\
\mathbf{a} \\
\mathbf{n} \\
\mathbf{e} \\
\mathbf{t}\end{array}$ & $\begin{array}{l}\text { H\&M evaluates the environmental impacts along the value } \\
\text { chain: design (to create sustainable fashion without } \\
\text { compromising on style, design, quality or price, minimising } \\
\text { what ends up, and looking at the impact of materials on the } \\
\text { environment); raw materials (making the right choices at } \\
\text { this stage to reduce environmental and social impacts); } \\
\text { fabric and yarn production (concerns regarding water, } \\
\text { chemicals and working conditions as well as greenhouse } \\
\text { gas emissions); garment production (high social and } \\
\text { environmental standards); transport (it causes } \\
\text { approximately 6\% of the greenhouse gas emissions in a } \\
\text { garment's lifecycle; through the right modes of transport, } \\
\text { H\&M can reduce this impact); sales (ensuring an healthy } \\
\text { working environment); use (to inspire customers to be more } \\
\text { conscious in the way they care for their clothes, for example } \\
\text { as regards washing and drying, and make it easy and } \\
\text { effortless to recycle any garment that might no longer be } \\
\text { wanted). }\end{array}$ & $\begin{array}{l}\text { Inidtex adopts a circular economy model: design (Clear to } \\
\text { Wear Safe to Wear); raw materials (Right to Wear + The } \\
\text { List by Inditex); wet processes of dyeing, printing, washing, } \\
\text { tanning and finishing (Green to Wear Ready to } \\
\text { Manufacture); manufacturing (Clear to Wear Safe to Wear } \\
\text { Picking); logistics (Packaging optimization programme used } \\
\text { throughout the whole supply chain, in collaboration with } \\
\text { suppliers); stores (Eco-efficient Store Manual Includes all } \\
\text { of the efficiency and sustainability requirements fulfilled by } \\
\text { stores in terms of their construction, facilities and the } \\
\text { activities carried out such as waste management); labelling } \\
\text { (Technical standard that identifies the most sustainable } \\
\text { items, produced with raw materials such as organic cotton } \\
\text { or TENCEL ® Lyocell; with recycled materials or with } \\
\text { technology that uses renewable energy, or processes that } \\
\text { use water and energy efficiently. At Zara, the Join Life label } \\
\text { identifies these items); re-use and recycling (Closing the } \\
\text { Loop Project). }\end{array}$ \\
\hline $\begin{array}{l}\mathbf{F} \\
\mathbf{o} \\
\mathbf{c} \\
\mathbf{u} \\
\mathbf{S}\end{array}$ & $\begin{array}{l}\text { Since challenges such as long working hours, lack of } \\
\text { functioning industrial relations, low wages and workplace } \\
\text { safety are key issues in many markets, H\&M uses its } \\
\text { influence to promote better working conditions, ensuring } \\
\text { the respect of human rights and reducing environmental } \\
\text { impacts throughout the value chain. H\&M's business is to } \\
\text { be characterised by a fundamental respect for the } \\
\text { individual, where everyone is of equal value. This applies to } \\
\text { everything from fair wages, reasonable working hours and } \\
\text { freedom of association to the opportunity to grow and } \\
\text { develop within the company. The company's values- the } \\
\text { H\&M spirit - are based partly on the ability of the } \\
\text { employees to use their common sense to take responsibility } \\
\text { and use their initiative. The diversity among employees as } \\
\text { age, gender, ethnicity, etc. is considered as a valuable asset } \\
\text { for the company. }\end{array}$ & $\begin{array}{l}\text { Traceability of the supply chain. Inditex works with external } \\
\text { suppliers and their factories with the aim to guarantee that } \\
\text { every item is manufactured in maximum compliance with } \\
\text { legislation on labour, the environment and product health } \\
\text { and safety. All suppliers are required to register the } \\
\text { factories involved in production, allowing Inditex to verify } \\
\text { their production capacity. By doing so, Inditex expects to } \\
\text { monitor its worldwide supply chain and minimizes the } \\
\text { possibility of outs ourcing. The integrity of the supply chain } \\
\text { is directly linked to the protection of human rights } \\
\text { established in the United Nations Guiding Principles on } \\
\text { Business and Human Rights and various Sustainable } \\
\text { Development Goals (SDGs). Developing everybody's } \\
\text { talent: Inditex has } 152,854 \text { people of } 90 \text { nationalities on its } \\
\text { payroll and wants to be close to each employee, believes in } \\
\text { their talent and provides a favourable working environment } \\
\text { to promote their development. Contribution to community } \\
\text { welfare: To create value for society while creating value for } \\
\text { the business is the fundamental target of Inditex's } \\
\text { community investment programme. This creation of shared } \\
\text { value seeks to contribute to the UN Sustainable } \\
\text { Development Goals and ultimately to improve people's } \\
\text { lives. }\end{array}$ \\
\hline
\end{tabular}

Source: Companies' 2015 Sustainability Report and Annual Report, and websites 
Table 3: Focus on profit, planet and people at LVMH and Kering

\begin{tabular}{|c|c|c|}
\hline & LVMH & KERING \\
\hline $\begin{array}{ll}\text { F } & \\
\text { o } & \text { p } \\
\text { c } & \text { r } \\
\text { u } & \text { o } \\
\text { s } & \mathbf{f} \\
& \text { i } \\
\text { o } & \text { t } \\
\text { n } & \end{array}$ & $\begin{array}{l}\text { The Group comprises } 70 \text { Houses that create high quality } \\
\text { products and it is the only group present in all five major } \\
\text { sectors of the luxury market: Wines \& Spirits, Fashion \& } \\
\text { Leather Goods, Perfumes \& Cosmetics, Watches \& Jewelry } \\
\text { and Selective Retailing. It combines economic growth, } \\
\text { sustainability and commitment to creativity and excellence. } \\
\text { It aims at strengthening its competitive position as a global } \\
\text { leader, and at setting the standard for managing and } \\
\text { developing high-quality brands. }\end{array}$ & $\begin{array}{l}\text { In } 2015 \text {, Kering had } 11.584 \text { billion euro of revenue coming } \\
\text { from luxury }(68 \%) \text { and sport \& Lifestyle ( } 32 \%) \text { through } \\
1,264 \text { directly operated stores (luxury division). From a } \\
\text { financial and operational point of view, Kering's balanced } \\
\text { and diversified business model enables the Group to } \\
\text { combine growth and profitability. The Kering strategy is } \\
\text { based on four main areas of focus: } \\
\text { - A multi-brand model; } \\
\text { - Organic growth as a priority; } \\
\text { - Value creation: through the organisational structures and } \\
\text { working methods it has introduced; } \\
\text { - Sustainable development: this goal underpins all actions. }\end{array}$ \\
\hline $\begin{array}{l}\mathbf{F} \\
\mathbf{o} \\
\mathbf{c} \\
\mathbf{u} \\
\mathbf{s} \\
\mathbf{0} \\
\mathbf{n} \\
\mathbf{p} \\
\mathbf{l} \\
\mathbf{a} \\
\mathbf{n} \\
\mathbf{e} \\
\mathbf{t}\end{array}$ & $\begin{array}{l}\text { The Environmental Department of LVMH works together } \\
\text { with the Houses in order to reach an exemplary } \\
\text { environmental performance. In 2001, Bernard Arnault } \\
\text { signed the Environmental Charter that defines the Group's } \\
\text { goals and strategy: Aim for a high level of environmental } \\
\text { performance; Foster a collective commitment; Control } \\
\text { environmental risks; Design high-quality products by } \\
\text { integrating environmental innovation and creativity; Pursue } \\
\text { commitments beyond the company (LVMH website). } \\
\text { In 2012, the LIFE program was developed to embed } \\
\text { environmental factors more deeply in managerial processes, } \\
\text { facilitate the development of new environmental } \\
\text { management tools, and integrate the changes and } \\
\text { improvements achieved thanks to innovative practices at } \\
\text { LVMH Houses. LVMH works to preserve the planet's } \\
\text { resources, to design and develop products that are } \\
\text { compatible with environmental concerns, to report on its } \\
\text { policies, projects, and the progress achieved in meeting } \\
\text { objectives. It wants to contribute to an environmental } \\
\text { protection above and beyond the factors directly related to } \\
\text { operations, by entering into active partnerships with } \\
\text { cooperating business groups, local authorities and } \\
\text { associations. }\end{array}$ & $\begin{array}{l}\text { The "Environmental Profit \& Loss" Account (EP\&L) is the } \\
\text { tool developed by Kering to measure and monetise the } \\
\text { environmental impact of its own operations and its supply } \\
\text { chains. The EP\&L tool measures six environmental impacts } \\
\text { (air emissions, GHGs, land use, waste, water consumption } \\
\text { and water pollution) in five areas (store warehouse offices, } \\
\text { assembly, manufacturing, raw material processing, raw } \\
\text { material production). } \\
\text { Key insights revealed by the EP\&L include the fact that } \\
93 \% \text { of the total environmental impact is attributable to the } \\
\text { supply chain, half of which is related to the production of } \\
\text { raw materials, and } 35 \% \text { of the Group's total environmental } \\
\text { impact comes from greenhouse gas emissions. }\end{array}$ \\
\hline $\begin{array}{l}\text { F } \\
\text { o } \\
\text { c } \\
\text { u } \\
\text { s } \\
\text { o } \\
\text { n } \\
\text { p } \\
\text { e } \\
\text { o } \\
\text { p } \\
\text { l } \\
\text { e }\end{array}$ & $\begin{array}{l}\text { The Group aims at encouraging all employees to reach their } \\
\text { full career potential and achieve their aspirations, at } \\
\text { developing diversity and the wealth of human resources in } \\
\text { all the countries where it operates. Moreover, it contributes } \\
\text { to the knowledge and preservation of its crafts and } \\
\text { expertise as artisans and designers. } \\
\text { 1. Developing talent and skills: Identifying and recruiting } \\
\text { talent, along with preserving strategic skills and expertise. } 2 \text {. } \\
\text { Managing quality of life at work } \\
\text { 3. Preventing discrimination and respecting individuality: } \\
\text { The people who make up LVMH constitute the Group's } \\
\text { most prized as set. The LVMH prevents any risk of } \\
\text { discrimination, and aims to respect each person's } \\
\text { individuality. } \\
\text { 4. Supporting local communities and regional development. } \\
\text { The Group's companies are committed to developing their } \\
\text { businesses while addressing the specific social and } \\
\text { economic needs of the regions in which they operate. }\end{array}$ & $\begin{array}{l}\text { Kering continually invests in development tools and } \\
\text { programmes to give employees the support they need to } \\
\text { go beyond their natural limits, personally and } \\
\text { professionally. Three main trends support the Kering effect } \\
\text { on HR: global, digital and sustainability. Company } \\
\text { evaluation processes encourage employees to express their } \\
\text { desires for training, development and career advancement. } \\
\text { The Kering Leadership Model (KLM) applies to all brands } \\
\text { and countries and defines what it means to be a leader at } \\
\text { Kering: it is a shared language that enables the group to } \\
\text { achieve success together. KLM serves as a compass, with } \\
\text { four themes: Create with a vision, Drive and deliver, Engage } \\
\text { with all and Build from heritage to legacy. Finding the right } \\
\text { balance among these themes - in terms of how to behave } \\
\text { and perform tasks - allows employees to be more creative, } \\
\text { develop their careers, exceed their goals and, ultimately, } \\
\text { contribute to sustainable performance. Each year Kering } \\
\text { organises the Kering Sustainability Awards, a competition } \\
\text { that is open to all Group employees. Regardless of their } \\
\text { profession, employees can submit a team project outlining a } \\
\text { more efficient process or a more sustainable product. }\end{array}$ \\
\hline
\end{tabular}

Source: Companies' 2015 Sustainability Report and Annual Report, and websites 
With regard to the environmental sustainability, both fast fashion companies adopt a circular model where the environmental impact of each activity (from product design to store management) is evaluated to reduce the use of natural resources. Moreover, they look for new technologies able to moderate the waste and emphasize recycling policy. Both companies are really committed to safeguard the planet and realize many initiatives to this purpose, such as, for example, the use of renewable electricity, the reduction of total emissions, and the adoption of more efficient lighting systems for stores.

Finally, the attention about social sustainability focuses on: traceability and integrity of the supply chain (better working conditions, fair wages, health and safety); improvement of working conditions for employees; and social policies developed in the communities where companies operate.

In the luxury market, the selected companies operate through a diversified multibrand portfolio in different business areas (perfumes, fashion, watches, and jewellery) and pursue an economic growth based on excellence, creativity and sustainability. Both the luxury groups pay a great attention to the planet safeguard, LVMH through an environmental department and Kering with the Environmental Profit and Loss Account (EP\&L) work to preserve the ecological environment, to use renewable resources and to pursue an environmental protection.

From a social sustainability's point of view, the considered luxury groups are focused on their human resources by helping employees to growth, improving their skills and rewarding the most talented. Beside to prevent any discrimination and provide employees with a good working environment, luxury companies need to preserve the artisanship and expertise built over time and difficult to re-acquire rapidly. Consequently, they perform many initiatives that underline and safeguard the artistic abilities of their personnel such as, for example, the recent initiative called 'Les Journées Particulières' of LVMH that has created the Institut des Métiers d'Excellence and the Ecole des Savoir-Faire Maroquiniers Louis Vuitton to promote craftsmanship and design professions (LVMH website).

Similarly, numerous Kering brands offer to the most talented employees training programs beside to sustain some technical schools of craftsmanship to guarantee employment in specific regions. For example, it is the case of the Brioni Scuola di Alta Sartoria or Bottega Veneta Scuola Della Pelletteria, and the Alta Scuola di Pelletteria, which Gucci helped to establish. Moreover, Kering has a partnership with HEC Paris School of Management's Luxury Chair and supports the 'Luxury Certificate' (Kering website).

\section{Conclusions and Emerging Issues}

The conducted analysis has highlighted that the management of corporate sustainability in fast fashion and luxury companies is not so different. All companies consider corporate sustainability as a crucial driver of growth and invest resources and capabilities in seeking new innovative technologies and procedures aimed at pursuing a sustainable development where profit, planet and people are balanced. Obviously, some dissimilarities exist among the sustainability priorities recognized by companies in fast fashion market and luxury market. 
In particular, fast fashion companies, which sell millions of clothes every years, focus their environmental sustainability policy on adopting a circular model that encourages the recycling policy, beyond to reduce the use of natural resources and chemicals widely employed and heavily polluting for the environment. In addition, from a social sustainability point of view, they are primarily committed to providing suppliers and their factories with better life and working conditions and in making more transparent their supply chains. In fact, in fast fashion market, the main attention of companies on sustainability issues pertains to operations and, therefore, they realize actions such as audit teams to verify compliance to the code of conduct, classroom training for suppliers, visits, interviews, and factory rating systems.

Instead, luxury companies, which employ materials that are scarce and rare in nature, need to preserve them through actions and structures created ad hoc, such as the Environmental Department at LVMH, or the EP\&L program at Kering. Similarly, from a social sustainability perspective, they need to retain and engage their human capital and, above all, to preserve over time the artistic and professional skills necessary to manufacture luxury items. For this reason, luxury companies invest and enter into partnership with schools where the professions of luxury manufacturing such as tailoring and dressmaking are taught.

The paper aimed at contributing to the academic literature on sustainable fashion and luxury. However, it has several limitations, the most evident of which refers to the size of case studies and the fact that findings cannot be generalized. To overcome this problem, future research could examine other fashion companies in order to investigate how they manage their economic, social and environmental sustainability's policies.

In conclusion, it is possible to assert that fashion and luxury companies aiming at being perceived as sustainable should manage their economic, environmental and social policies in an integrated way in order to consolidate their competitive position by clearly dissociating from a simple "green washing" that is widespread among many competitors.

\section{Bibliography}

Achabou, M. A., \& Dekhili, S. (2013). Luxury and sustainable development: Is there a match?. Journal of Business Research, 66(10), 1896-1903.

http://dx.doi.org/10.1016/j.jbusres.2013.02.011

Arrigo E. (2013). Corporate responsibility management in fast fashion companies. The Gap Inc. case, Journal of Fashion Marketing and Management, 17(2), 175-189.

http://dx.doi.org/10.1108/JFMM-10-2011-0074

Arrigo E. (2009), Market-driven management, global competition and corporate responsibility, Symphonya. Emerging Issues in Management (symphonya.unimib.it), 1, 51-67. http://dx.doi.org/10.4468/2009.1.06arrigo

Bansal, P. (2005). Evolving sustainably: A longitudinal study of corporate sustainable development. Strategic Management Journal, 26(3), 197-218.

http://dx.doi.org/10.1002/smj.441

Black, S. (Ed.). (2013). The sustainable fashion handbook. Thames \& Hudson. 
Brondoni, S.M. (2008). Market-driven management, competitive space and global network, Symphonya. Emerging Issues in Management (symphonya.unimib.it), 1, 14-27. http://dx.doi.org/10.4468/2008.1.02brondoni

Brondoni, S.M. (2014). Global Capitalism and Sustainable Growth. From Global Products to Network Globalisation, Symphonya. Emerging Issues in Management (symphonya.unimib.it), 1, $10-31$ http://dx.doi.org/10.4468/2014.1.02brondoni

Carcano, L. (2013). Strategic Management and Sustainability in Luxury Companies. Sustainable Luxury: A special theme issue of The Journal of Corporate Citizenship, 52, 36.

Cavender, R., \& H. Kincade, D. (2014). Management of a luxury brand: dimensions and subvariables from a case study of LVMH. Journal of Fashion Marketing and Management, 18(2), 231-248.

http://dx.doi.org/10.1108/JFMM-03-2013-0041

Cervellon, M. C., \& Shammas, L. (2013). The value of sustainable luxury in mature markets: A customer-based approach. The Journal of Corporate Citizenship, 52, 90-102.

Chevalier, M., \& Mazzalovo, G. (2012). Luxury brand management. A world of privilege, 2nd edition, Hoboken/New Jersey.

Choi, T. M., Liu, N., Liu, S. C., Mak, J., \& To, Y. T. (2010). Fast fashion brand extensions: An empirical study of consumer preferences. Journal of Brand Management, 17(7), 472-487.

http://dx.doi.org/10.1057/bm.2010.8

De Brito, M. P., Carbone, V., \& Blanquart, C. M. (2008). Towards a sustainable fashion retail supply chain in Europe: Organization and performance. International Journal of Production Economics, 114(2), 534-553.

http://dx.doi.org/10.1016/j.ijpe.2007.06.012

Dillick, T., \& Hockerts, K. (2002). Beyond the business case for corporate sustainability. Business Strategy and the Environment, 11, 130-141.

http://dx.doi.org/10.1002/bse.323

Elkington, J. (1994). Towards the sustainable corporation: Win-win-win business strategies for sustainable development. California Management Review, 36(2), 90-100.

http://dx.doi.org/10.2307/41165746

Elkington, J. (1997). Cannibals with forks. The triple bottom line of 21 st century.

Epstein, M.J. (2008). Implementing corporate sustainability: measuring and managing social and environmental impacts. Strategic Finance, 89(7), 24-31.

Freeman, R. E. (2010). Strategic management: A stakeholder approach. Cambridge University Press.

Gardetti, M. A., \& Muthu, S. S. (2015). Handbook of sustainable luxury textiles and fashion (Vol. 1). Springer.

Gardetti, M. A., \& Torres, A. L. (Eds.). (2013). Sustainability in fashion and textiles: values, design, production and consumption. Greenleaf Publishing.

Gnecchi Flavio (2013) Retailing, Private Label and Global Competition, Symphonya. Emerging Issues in Management (symphonya.unimib.it), 2, 79-87.

http://dx.doi.org/10.4468/2013.2.06gnecchi

H\&M Annual Report, 2015.

H\&M Sustainability Report, 2015.

Inditex Annual Report, 2015.

Jia, P., Govindan, K., Choi, T. M., \& Rajendran, S. (2015). Supplier selection problems in fashion business operations with sustainability considerations. Sustainability, 7(2), 1603-1619.

http://dx.doi.org/10.3390/su7021603

Joy, A., Sherry Jr, J. F., Venkatesh, A., Wang, J., \& Chan, R. (2012). Fast fashion, sustainability, and the ethical appeal of luxury brands. Fashion Theory, 16(3), 273-295. 
Kapferer, J. N. (2010). All that glitters is not green: The challenge of sustainable luxury. European Business Review, 40-45.

Kapferer, J. N., \& Michaut-Denizeau, A. (2014). Is luxury compatible with sustainability? Luxury consumers' viewpoint. Journal of Brand Management, 21(1), 1-22.

http://dx.doi.org/10.1057/bm.2013.19

Keegan, W. H., \& Green, M. G. (2013). Global Marketing. Pearson.

Kering Annual Report, 2015.

Kering Sustainability Report, 2015.

Khurana, K., \& Ricchetti, M. (2015). Two decades of sustainable supply chain management in the fashion business, an appraisal. Journal of Fashion Marketing and Management, 20(1), 1361-2026. http://dx.doi.org/10.1108/JFMM-05-2015-0040

Krippendorff, K. (2012). Content analysis: An introduction to its methodology. Sage.

Kim, H., Jung Choo, H., \& Yoon, N. (2013). The motivational drivers of fast fashion avoidance. Journal of Fashion Marketing and Management: An International Journal, 17(2), 243260.

http://dx.doi.org/10.1108/JFMM-10-2011-0070

Kozlowski, A., Searcy, C., \& Bardecki, M. (2015). Corporate sustainability reporting in the apparel industry: an analysis of indicators disclosed. International Journal of Productivity and Performance Management, 64(3), 377-397.

http://dx.doi.org/10.1108/IJPPM-10-2014-0152

Lambin, J J. (2009). Capitalism and Sustainable Development, Symphonya. Emerging Issues in Management (symphonya.unimib.it), 2, 3-9.

http://dx.doi.org/10.4468/2009.2.02lambin

Li, E., Liu, W. S., Yuan, V., Lam, E., \& Lam, M. (2015). Democratization of Fashion: a Study of Co-Creation of Cultural Heritage. NA-Advances in Consumer Research Volume 43.

LVMH Annual Report, 2015.

LVMH CSR Report, 2015.

Mosca F. (2008). Market-driven management in fashion and luxury industries, Symphonya. Emerging Issues in Management (symphonya.unimib.it), 1, 65-71. http://dx.doi.org/10.4468/2008.1.06mosca

Nidumolu R., Prahalad C.K., Rangaswami M.R. (2009). "Why Sustainability Is Now the Key Driver of Innovation", Harvard Business Review, September, 1-11.

Pedersen, E. R. G., \& Andersen, K. R. (2015). Sustainability innovators and anchor draggers: a global expert study on sustainable fashion. Journal of Fashion Marketing and Management, 19(3), 315-327.

http://dx.doi.org/10.1108/JFMM-08-2014-0059

Perrini, F. \& Vurro, C. (2010). Corporate sustainability, intangible assets accumulation and competitive advantage constraints, Symphonya. Emerging Issues in Management (symphonya.unimib.it), 2, 25-38.

http://dx.doi.org/10.4468/2010.2.03perrini.vurro

Petrick, I. J., \& Simpson, T. W. (2013). 3D printing disrupts manufacturing: how economies of one create new rules of competition. Research-Technology Management, 56(6), 12-16. http://dx.doi.org/10.5437/08956308X5606193

Riboldazzi, S. (2005). Global retailers and competitive customer value. Symphonya-Emerging Issues in Management (symphonya.unimib.it), 2, 77-87. http://dx.doi.org/10.4468/2005.2.07riboldazzi

Salvioni, D.M. \& Bosetti, L. (2014). Sustainable development and corporate communication in global markets, Symphonya. Emerging Issues in Management (symphonya.unimib.it), 1, 32-51. http://dx.doi.org/10.4468/2014.1.03salvioni.bosetti 
Tate, W. L., Ellram, L. M., \& Kirchoff, J. F. (2010). Corporate social responsibility reports: a thematic analysis related to supply chain management. Journal of Supply Chain Management, 46(1), 19-44.

http://dx.doi.org/10.1111/j.1745-493X.2009.03184.x

Turker, D., \& Altuntas, C. (2014). Sustainable supply chain management in the fast fashion industry: An analysis of corporate reports. European Management Journal, 32(5), 837-849.

http://dx.doi.org/10.1016/j.emj.2014.02.001

Wiedmann, K. P., \& Hennigs, N. (2013). Luxury marketing. A challenge for theory and Practice, Springer.

Yin, R. K. (2013). Case study research: Design and methods. Sage publications. 